\title{
Women's local knowledge of water resources and adaptation to landscape change in the mountains of Veracruz, Mexico
}

\author{
Maria Kernecker $^{1}$, Christian R. Vogl $^{2}$ and Araceli Aguilar Meléndez ${ }^{3}$
}

\begin{abstract}
Rural development shaped by global pressures aims to improve livelihoods and market access in remote communities. However, rural development measures can alter landscapes, and change the embedded natural resources and access to them. In Mexico, rural women and their livelihoods are frequently most affected by changes in water resources. This study focused on women in Coatitilán, a small community (population 255) in the mountains of Veracruz, Mexico. A road construction project blocked the main pipe that distributes water throughout the community. Also, river water was unusable for women living downstream of a trout cultivation project. Participant observation and interviews were used to determine how women in Coatitilán dealt with limited water access and reduced quality. Women's local knowledge of the landscape highlighted the location of water springs that had previously been used infrequently, and underlined the importance of vegetation in controlling water resources. Women's local knowledge of climate demonstrated local expressions for weather, and highlighted the importance of prayer for dealing with unforeseen events. Kinship provided several women with access to water from privately owned springs. This study shows that women in Coatitilán adapted their water management by relying on their local knowledge of landscape and climate, and on social networks. These results suggest that women's local knowledge could play an important role in planning development projects, and it helps women adapt to abrupt changes.
\end{abstract}

Key Words: Mexico; resilience; rural development; water use and management

\section{INTRODUCTION}

Developments in agriculture and society from international to local scales have transformed rural landscapes (Antrop 2005, Arnberger and Eder 2011). Understanding the interrelated environmental and social issues associated with landscape change remains a central challenge for sustainability science (Lambin and Meyfroidt 2010), despite increasing research on social-ecological systems in the past decades. Landscape change is caused by complex drivers at different scales (Fig. 1) that have feedbacks on people-ecosystem relationships (Fischer et al. 2015). At the global scale, agricultural production targeted at markets beyond the local setting has disregarded activities related to self-subsistence (Eakin et al. 2014). Moreover, the need for better access to urban markets has put increased pressure on rural regions to develop their infrastructure, and in some cases support inappropriate interventions that have led to rapid landscape change (Lambin et al. 2001), which has amplified the effects of global pressures on rural development policies (Ellis 2000). As rural livelihoods have shifted largely from agriculture to becoming more wage-labor oriented, farmers increasingly migrate (Bell et al. 2010) or restructure their land use (Garcia-Barrios et al. 2009), with both direct and indirect consequences for communities and their surrounding landscapes. The land use changes associated with those livelihood shifts (Coomes and Burt 1997, Lambin et al. 2013) can degrade ecosystems and their ability to provide goods and services that are necessary for rural community well-being (Erb et al. 2009). The paradox is that landscape change is often caused by decisions made outside the local rural context (Biggs et al. 2015). However, it is the members of the rural communities who are immediately affected by landscape change and have to adapt the way they use, manage, conserve, or deal with altered ecosystems and the natural resources therein.
Fig. 1. Conceptual model of reciprocal relationships between people and their environment (adapted from Fischer et al. 2015).

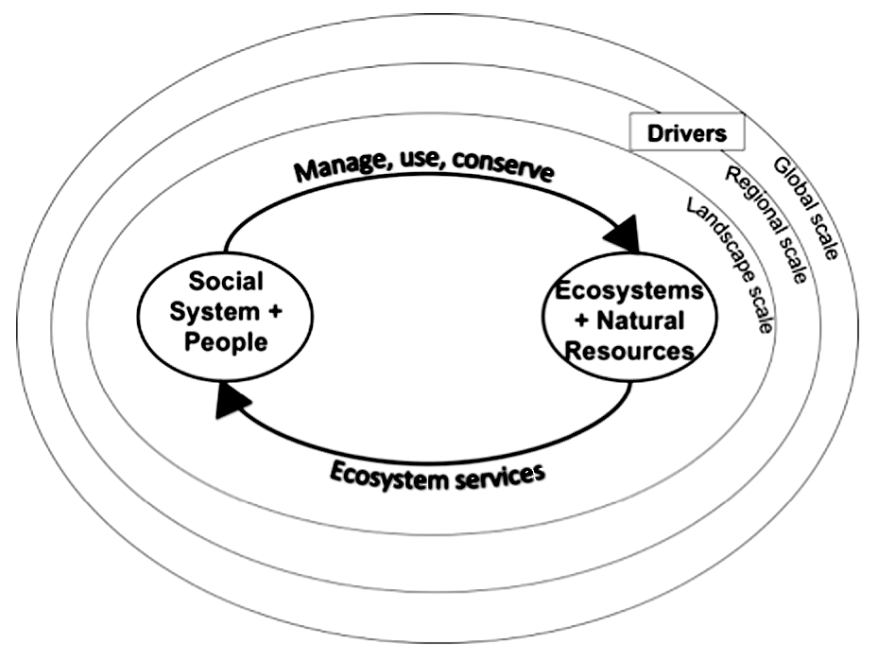

Rural women may be especially vulnerable to landscape change that is occurring in developing regions due to their limited access to participation in decision-making processes and control over changes (FAO 2015) regarding their communities and landscapes. This is counterintuitive given that women have continued to play a dominant role in agricultural production, and therefore in shaping rural landscapes throughout the past decade. Not only do women have to adapt to changes that affect their households, but they also have to increase their responsibility for agriculture

${ }^{1}$ Leibniz Centre for Agricultural Landscape Research (ZALF) e.V., ${ }^{2}$ University of Natural Resources and Life Sciences, Vienna, ${ }^{3}$ Centro de Investigaciones Tropicales, Universidad Veracruzana 
activities. Women produce $60-80 \%$ of the food in developing regions, and are major stakeholders in development issues related to water access (UNESCO 2015). Since women are often excluded from management and planning decisions regarding water resources, they often have to develop their own strategies for dealing with water (Ray 2007). For example, a classic study by Judith Carney (1986) showed that with the arrival of pump irrigation in The Gambia, rice went from being a traditional women's crop to a new men's crop after which men started to control both the farming and the revenues. This example highlights that rural development that focuses on water resources specifically affects women and their relationship to natural resources and ecosystem management. In another example from a Nepali irrigation scheme, female heads of household were able to use their allegedly vulnerable status to get access to water and to reduce their contribution to the required maintenance labor. In this case, women therefore adapted their water management by using social relationships (Zwarteveen 1997). Women remain excluded from rural development processes, but they adapt to the consequent changes, for example, through social networks. Women's local knowledge of landscape, ecosystems, and natural resources is expected to contribute to their adaptation to limited water access in rural regions and landscapes that are undergoing change.

Local knowledge is generally understood to be contextual knowledge that resource users have about their immediate environment (Blaikie 1985, Peet and Watts 1996, Barrera-Brassols and Zinck 2002), and is tightly embedded in their worldview and belief system, which inform practices associated with local knowledge (Berkes et al. 2000). As a result, resource users have a profound awareness of their local ecosystems that allows them to adapt their natural resource use as needed. More specifically, people can adapt the way they use landscapes and the associated natural resources based on what they know about ecological processes (Berkes et al. 1998b). For this reason, local knowledge has received increasing attention for its capacity to provide insight into landscapes and ecosystem services, which can be used to make ecosystem management more sustainable (Wu 2013). For example, in the Pyrennes, pastoralists have a deep understanding of the relationships between terrain, weather, soils, plant growth and nutritional value for livestock, which serve as indicators of forage quality. This knowledge is used to match animal demands with available forage, regardless of climate conditions, and thus provides a monitoring scheme for grazing management (Fernandez-Gimenez and Estaque 2012). As such, qualitatively monitoring and managing resources informs local knowledge during phases of resource use and conservation, and can therefore build resilience at the landscape level (Berkes and Folke 2002). Resilience is the capacity of the social-ecological system, or community and the landscape it is embedded in, to continue providing the desired ecosystem services (e.g., crop production, freshwater provisioning) in the face of both unexpected shocks (e.g., climate events, infrastructure development) and more slow, ongoing change and development. Exploring how the local knowledge of specific groups of resource users can contribute to social-ecological resilience is particularly interesting, since globally occurring demographic shifts are changing resource use patterns in rural communities and their immediate landscapes.
Given previous findings, we expect that women's local knowledge, in combination with social networks, can facilitate women's adaptation to abrupt landscape changes. Within this context, we investigate (1) the key factors related to local knowledge and social networks for adapting water management, and (2) what the implications of local knowledge are for landscape governance. We conducted our study in Coatitilán, a small community in eastern Mexico, for two reasons. First, in 2007, when fieldwork was conducted, it remained an isolated region that was undergoing major road construction and was adjusting to a recent development project aimed at producing trout for market specialization. Second, it is representative of small rural communities that are affected by complex, multiscale drivers of landscape change. We acknowledge that landscape is the "result of complex and closely interwoven natural and human processes" (Plieninger and Bieling 2012, and similarly defined by Urquijo and Barrera Bassols 2008 and Urquijo and Bocco 2011), but we use the term in reference to the immediate biophysical environment that a rural community is part of and uses.

\section{METHODS}

\section{Participatory methods and study group}

The study was conducted from July to September 2007. During the first phase, Coatitilán's land use history was recorded in meetings with the community historian, local librarians, and other researchers who had previously done applied research in the area. For the remainder of the time, participatory methods were used to investigate women's adaptation to limited water resources in Coatitilán. These methods seem appropriate for providing a general understanding of the key factors related to local knowledge, social networks, and adaptation to landscape change, particularly given the short period of time the community was studied and the small size of the community.

The first author asked for and received free, prior, and informed consent in the form of an oral agreement from all women the researcher engaged with. The research project was also registered at the municipal office in Xico to inform officials of the project.

\section{Participant observation}

Contact with the women in the community was achieved via one woman who served as a community medical worker and was responsible for recording small child and women's health throughout Coatitilán. This woman thus served as the "cultural broker" (Newing 2011), who facilitated the first author's participation in everyday life in the community and introduced her to the women she visited on her rounds of controlling women's and children's health. The first author did not live in the community to avoid bias or strong association by living with any particular family. Each day, the first author took the bus from Xico in the morning and visited different women and their families. The snowball method allowed the first author to then be introduced to other women (Bernard 2002).

Participant observation formed the basis of the field research. This method is unstructured and interactive, and is used to observe people in their everyday life. The researcher can accompany individuals or groups of people by observing what they do, while simultaneously participating in the observed activities. Thereby, the routine of the community members is 
Table 1. Interview guide categories and sample questions.

\begin{tabular}{|c|c|}
\hline \multirow[t]{3}{*}{ Practice } & What do you use water for? \\
\hline & Which rules guide who uses water, and how, when water is used? \\
\hline & How do water resources change throughout the day, throughout the year? \\
\hline \multirow[t]{5}{*}{ Knowledge } & How do you know what the weather will be? \\
\hline & Who do you ask for information about water if you need it? \\
\hline & Where do you get water? How do you know where to find it? \\
\hline & Why is water necessary? \\
\hline & When is there too much water? \\
\hline \multirow[t]{2}{*}{ Social organization } & Who controls water? \\
\hline & Who has access to water in the community? \\
\hline Worldview & Is there a God or Saint in charge of water, weather, or crops? \\
\hline \multirow[t]{2}{*}{ Language } & What kinds of water are there? \\
\hline & Which seasons are there? \\
\hline \multirow[t]{3}{*}{ Economy } & How does your family earn money? \\
\hline & Who leaves the community for work? Where do they go? \\
\hline & Who does their work when they are gone? \\
\hline \multirow[t]{3}{*}{ Climate } & How has climate changed in the past years? \\
\hline & Where do you get your information regarding weather and seasons? \\
\hline & What do you eat, when? \\
\hline
\end{tabular}

followed rather than being interfered with. The main benefit of using this method is that instead of gathering information for the study in a separate setting, the researcher can directly engage in conversation and activities with the community members (Newing 2011). One concern is that the community being studied will bias their responses according to what they think the researcher wants to hear. By using data saturation, this issue can be controlled. This means that the researcher continues observing and analyzing data until new themes no longer appear, and therefore arguably no new data are necessary (Glaser and Strauss 1967). For this study, participant observation was put into practice through active engagement in community life, particularly that of the women and their families, during meals, cooking, fire wood collection, etc. Observations were documented with constant note-taking. These notes and their interpretations provided the basis for the study (Bernard 2002). Participant observation was complimented with more structured methods, including interviews, mapping, and transect walks.

\section{Interviews}

Semistructured interviews were held with five women, and 14 unstructured interviews were conducted with women. Informal interviews were held with a number of women during visits throughout the study. The five semistructured interviews were based on interview guides with questions in different categories (Table 1). The categories were adapted to Berkes' (1999) levels of analysis in traditional knowledge and management systems because they helped structure questions according to different categories that could shape women's local knowledge of water resources and water management. These interviews were recorded and then transcribed. Semistructured interviewing shares the "freewheeling" qualities with unstructured interviews, although the interview guide that it is based on helped provide a more accurate comparison of information between women (Bernard 2002). A pretest of the interview guide was conducted with a woman in a neighboring community to ensure that the questions were linguistically appropriate and avoided bias in addressing the research question.
In the 14 unstructured interviews that were conducted, a loose plan based on the interview guide was followed. However, it had minimum control over women's responses, which allowed participants to express themselves at a pace with which they felt most comfortable (Bernard 2002).

Informal interviews are more like conversations than interviews. Keeping track requires persistent note-taking during and after conversations (Bernard 2002). Informal interviews with all conversation partners were used during the entire field study. These conversations loosely followed the same topics in semistructured and unstructured interviews, but did not always cover each topic. All interview data were validated through between-subject triangulation, in that several people were asked the same thing (Newing 2011).

Mapping and transect walk

Participatory mapping is where a group of participants creates a map of their region to show which landscape and community elements are the most predominant (Vogl et al. 2004). The mapping exercise provided insight into how women and their families considered the spatial relationships between homes, landscape elements, and natural resources. For this study, a group of adults gathered in one family's house. One of the young men was informally nominated to do the drawing and writing, during which time the rest of the participants pointed out what should be drawn and advised the young man accordingly. The mapping activity served as a basis for discussion of identifying important natural resources and landscape features. The resulting map helped focus interviews and plans for a transect walk. The transect walk was essentially a guided tour through the community, where the participants explained the most important landscape and water-related elements. This was done to validate the map features (Newing 2011).

\section{Data analysis}

Analysis of all observational information and interview data was qualitative. Notes from participant observation formed an important basis for the data used. Interviews were transcribed, 
and then all the text from observation notes and interviews was analyzed using open coding techniques to consolidate information into broad thematic groups that corresponded to interview guides and participant responses (Gibbs 2007). More specifically, coding was used as an indexing system that is comparable with annotation, where sections of text are marked with abbreviations where particular topics are addressed (Newing 2011). The information from the participatory map and transect walk was used to complement the observational and interview data. Much of the data was used to construct an agrarian calendar to support insight into women's local knowledge.

\section{Study area description}

The area is characterized by widely dispersed communities located between rivers and separated by ravines and steeply sloped hillsides. Communities are surrounded by extensive pastures and are characterized by sparsely scattered houses, each surrounded by corn and bean fields and gardens with fruit and flowers. Small parcels of differing land use reflect a system of production that works best on the steep inclines of the Cofre del Perote. Coatitilán lies at $2080 \mathrm{~m}$ above sea level. Soils are andosols, which are black soils that stem from volcanic ash and are highly fertile (Hoffmann 1993). Forests are categorized as humid montane forests (Williams-Lienera 2007).

The climate is temperate-humid, with an annual average temperature of about $19^{\circ} \mathrm{C}$, a rainy season that lasts from July to September, and a drier season that begins in February. The annual amount of precipitation is approximately $1769 \mathrm{~mm}$ (Servicio Meteorologico Nacional Database 2007).

Coatitilán is one of eight small communities in the municipality of Xico (Fig. 2). Xico is the second largest market town, $11 \mathrm{~km}$ away, and Xalapa is $25 \mathrm{~km}$ away. According to the 2005 census, there were 255 people living in a total of 44 houses in Coatitilán (INEGI 2005). Coatitilán has two primary schools, a community store, and a chapel. The small size of the community made it ideal for studying within a short time frame.

Coatitilán is part of an ejido (the term for shared land managed communally in Mexico) that is shared with several communities in the municipality of Xico, including Matlalapa, Micoxtla, Aquilitla, Pocitos, and Cuauhtemecatla. The ejido was founded in 1939 and spans 866 ha. The social structure is guided by the representatives of the ejido and the municipality of Xico (Hoffmann 1993). In 2007, there were no female ejido representatives.

\section{Women, their livelihoods, and water resources}

According to the 2005 census, there were 53 females in Coatitilán who were age 18 or older (INEGI 2005). These women were most likely to be actively involved in household management, tasks, and decision-making. Women were engaged in a number of livelihood activities. Together with the men, they worked in the milpa (agroecological system), an intercropping system of corn, bean, and squash, and associated wild and weedy plants, mushrooms, insects, and animals. The main crop element of the milpa system is maize; therefore, corn production is at the center of agricultural cycles. The women foraged for specialty wild plants to sell at the market, such as quelites, a wild spinach (Amaranthus hybridus L.), cala lilies (Zantedeschia aethiopica(L.) Spreng.), and capulines, a type of black cherry (Prunus salicifolia Kunth). Around the milpa systems or in their homegardens, the women and their families also grew flowers, vegetables, and herbs, such as chilies (wild and domesticated Capsicum annuum L. and domesticated Capsicum pubescens Ruiz \& Pavon) and epazote (Dysphania ambrosioides (L.) Mosyakin \& Clemants) for their own consumption and to sell at the market. Furthermore, they had cows, goats, pigs, and chickens that they raised for meat and dairy products, both for personal consumption and for selling (Hoffmann 1993).

Fig. 2. Location of Coatitilán in Veracruz, Mexico (C d-maps. com).

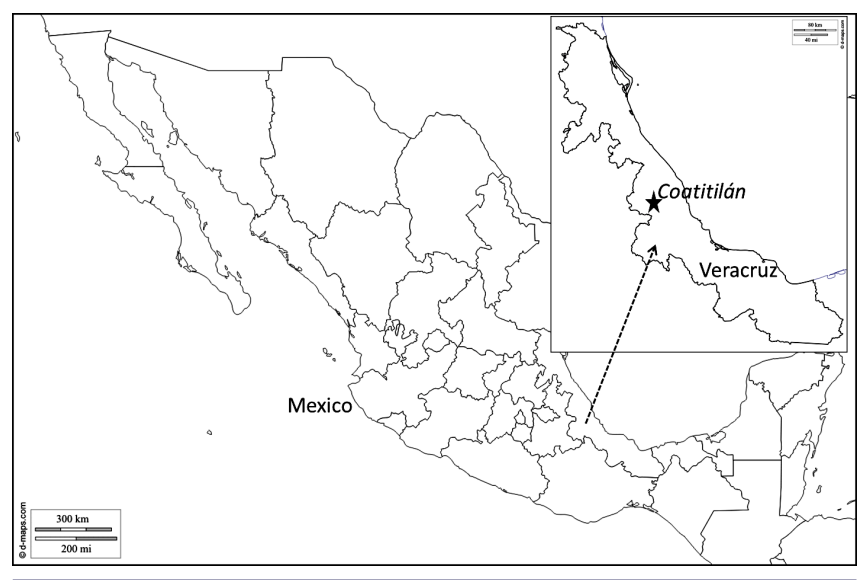

The central water supply system had been installed by the ejido in 1998, and was fed from the main reservoir. This caja de agua, or reservoir, collected water from a number of springs, and had simple tubing running from it through the entire village, and distributed water to most houses. It was also common for the community to use the Teocelo River as an open and shared washbasin (INEGI 2005, City Hall of Xico informants 8/2007, personal communication).

\section{Rural development and landscape change}

In the summer of 2007, a road construction project caused significant changes in the landscape, its ecosystems, and the central water supply system. The state-funded project for road construction aimed at connecting Coatitilán and other villages to Perote, a larger market town in Puebla, the neighboring state. The project was planned and carried out by ejido and municipal representatives from Xico. The road construction was positive for the community due to imminent connection to other towns, but was also problematic. The road construction project itself, however, reduced soil stability, which led to severe erosion issues. Mudslides covered pastures, which reduced forage for livestock, and destroyed some of the milpa, which reduced crop production. Most importantly for the context of this study, sediment clogged the water supply system, and some springs and streams became blocked, which made water access difficult, according to community members $(8 / 2007)$.

In addition to reduced water quantity from the water supply system, water quality was an issue. In the previous years, the Universidad Veracruzana had been involved in a development 
Table 2. Agricultural calendar for Coatitilán, divided by weather events and tasks in different livelihood domains.

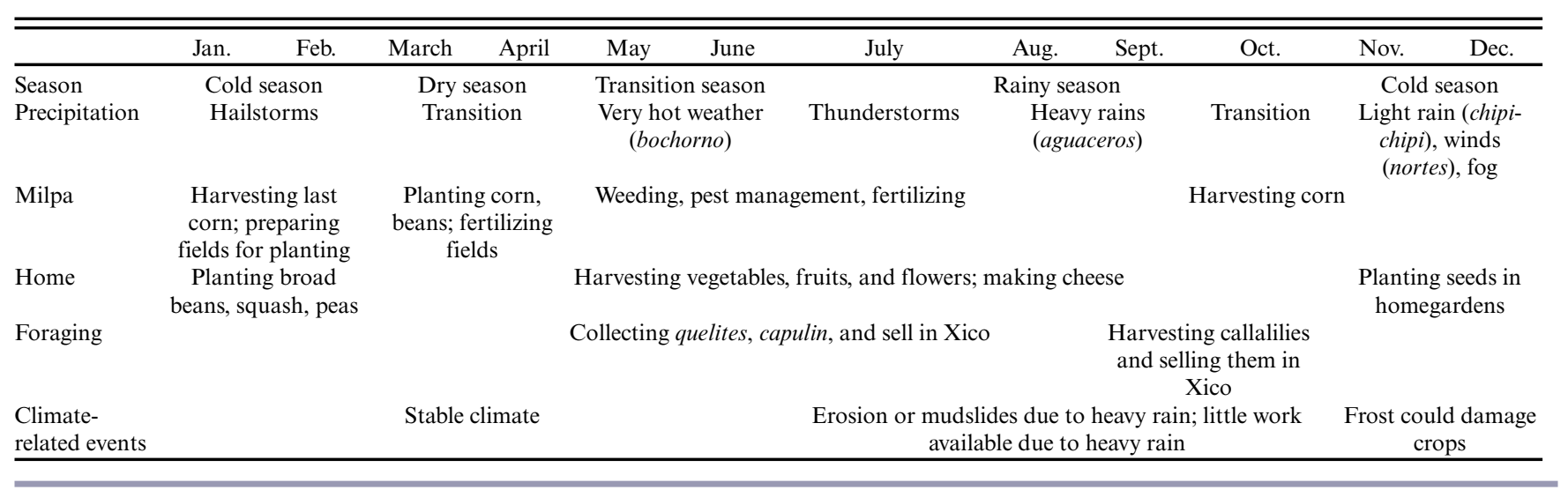

project that would provide the community with extra income through trout cultivation for external markets (Margana Cruz 2006). While the project was beneficial to the community for generating extra income, the women who lived downstream of the project did not approve because waste products from the trout cultivation reduced the water quality, which they relied on for washing clothes and dishes.

\section{RESULTS}

\section{Water use and water access}

Prior to the road construction, women used the water supply system for household (i.e., cooking, cleaning) and agricultural (i. e., watering homegardens, irrigating milpa) tasks. Also, before the trout cultivation project had been completed, women had also used river water for household tasks. This meant that the problems that women had during construction and after completion of the trout cultivation project were related to the reduced access to clean freshwater for their everyday tasks.

Water use depended on where women lived. If they lived downstream from the trout farm, the river water was unusable for household tasks, particularly during the rainy season when runoff from the trout farm was heavier. When women living further downstream noticed the river water quality was poor, they did not use it, and complained to municipal authorities, but with no notable consequences. Insufficient information was collected on upstream-downstream relationships, which would have allowed us to contribute to a discussion on the social dynamics and potential conflicts within this context.

Due to changes in water quantity and quality, women got their water elsewhere. In this particular case study, it meant that women revisited springs that were scattered throughout the landscape (which they had used previous to the installation of the central supply system) and used that spring water for washing dishes and clothing. Women preferred springs that were close to their homes. If a family in their social network had a private spring, women would go to that family with containers for retrieving water. Since these networks were based on kinship, there was no notable difficulty in women obtaining access to those private springs. Women considered the spring water clean, although the local health officials encouraged women to use chlorine drops to ensure the water was safe to use. No notable changes were observed in family dynamics, nor were conflicts due to unequal water access noted.

\section{Local knowledge}

In order to get a holistic understanding of the factors that could shape how women manage water, the local knowledge we studied encompassed everything from the water sources, vegetation, landscape, climate, language, and worldview. Women's knowledge of the landscape and the natural resources therein was linked to activities that women completed on a daily basis. Landscape and climate knowledge were linked via seasonal tasks around the home and in the field. Climate knowledge was directly linked with language and spirituality, and therefore provided a direct link to social networks within the community.

\section{Landscape, vegetation, and water resources}

Interviews, mapping, and the transect walk revealed that knowledge of landscape, water, and vegetation was strongly interrelated. Women observed that vegetation plays a central role in soil water retention and landscape structure maintenance. Specifically, forest and vegetation protect the mountainside by strengthening the soil. Trees and forest strengthen the soil, which prevents it from sliding and thereby damaging the pastures and milpas by "suffocating" vegetation. Excess rain in the rainy season can also instigate mudslides (por el agua), since the soil becomes too heavy with moisture. Construction and development of the landscape around Coatitilán made the soil weaker, which opens it up to the rain, and causes mudslides.

According to the mapping exercise and transect walk, vegetation also plays a key role in sustaining water resources throughout the landscape. To identify a spring, women look for trees. They attribute this to the fact that trees attract rain, which moistens the soil, and thereby replenishes springs with freshwater. In some cases, women say the water comes out of the ground because of trees. With a large number of trees, springs come into being. Likewise, having larger forests will attract more rain. More rain will regenerate spring water. Also, to women, more rain meant more water movement, which meant better water quality in more springs, and more streams. Without trees, women say there would be no water, which would lead to community suffering. If the 
Fig. 3. Map of Coatitilán drawn by Juan Galvez (2007). The backdrop is characterized by mountains (montañas), with two springs (nacimientos) identified. A large stream (arrollo de agua) flows from the mountains in the southwest to the east. A reservoir (caja de agua) is higher up on the hillside to the west of the community. Previous to the road construction, the water was distributed throughout Coatitilán by tubing (tubería de agua). Interspersed between the houses, as drawn in part of the community, are corn-bean fields (milpa) and pastures (pasto). Adjacent to the river (rio) is the trout cultivation basin (granja de trucha). The ravine along the river (barranca) is to the west of the trout cultivation basins. The school (escuela), kindergarten (gardin), and church (iglesia) are also depicted on the map.

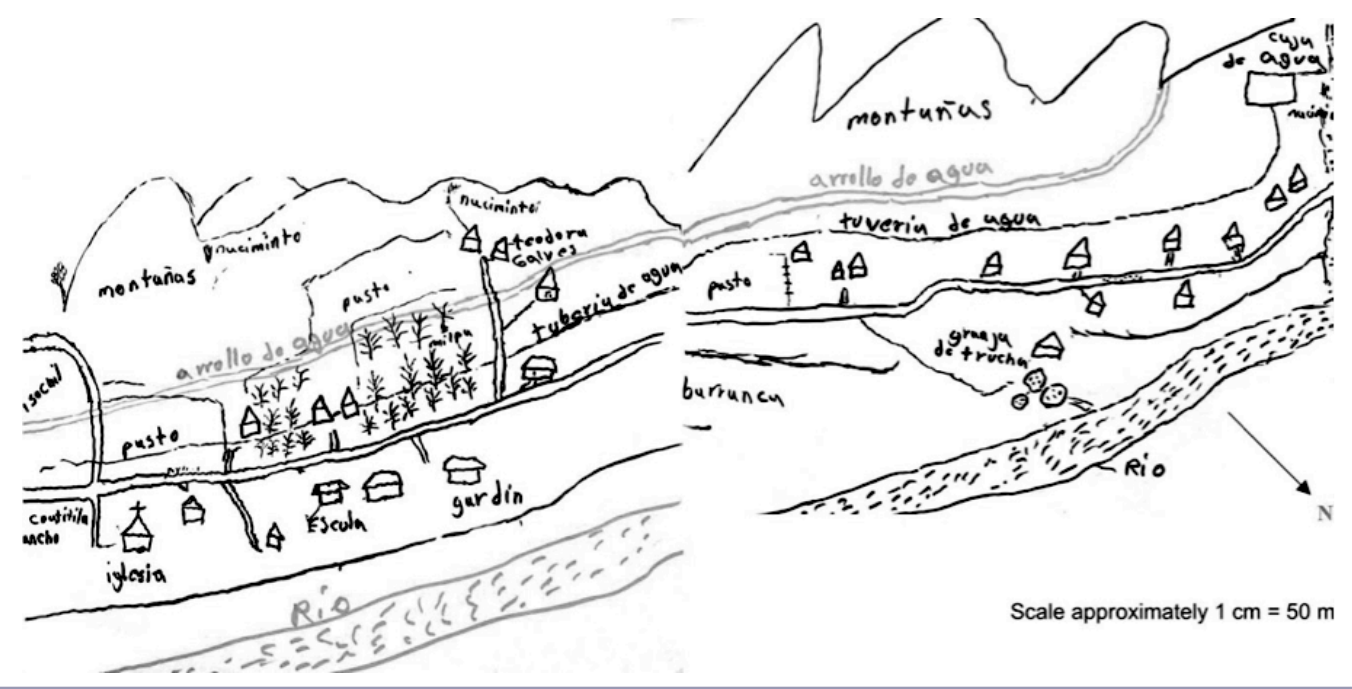

mountainsides could be successfully reforested, then the mountainside could be saved. In this way, climate, vegetation, and landscape are inseparable in women's local knowledge related to water resources. Moreover, their recognition that trees and vegetation were indelibly linked showed that there was an understanding of ecosystem processes that occur between different components.

Climate, language, and worldview

Climate is the defining force in the daily and yearly schedule of the inhabitants of Coatitilán. Women demonstrated local knowledge of climate that allowed them to forecast the weather both for daily schedules and yearly agricultural activities. Women also explained that the moon controls the weather and the seasons, and signals the agricultural activities. The moon is therefore an important part of the forecasting system, and is a deciding factor in climate, weather, and seasons. The moon manda, or sends, the rain. Women use the moon to know when it is time to start sowing seeds. It is expected that the stages of the moon come with increments of increasing water.

Women characterized the seasons by precipitation, temperature, and humidity. The lighter summer breezes that accompany the season's heavy rains characterize the rainy season from June through September. The winter storms, or nortes, mark the winter months, which arrive at the Gulf coast with polar winds, and bring with them the cold season that lasts from November to February. Lighter rains, locally referred to as both llovizna and chipichipi, are characteristic during this season. The rainy and cold season are separated by a dry period during April and May. During the cold months, the temperatures can drop to freezing (Table 2).
There is a general consensus based on direct observations that there has been a reduction in precipitation in the past years. Women explain that the variations in the effects of the hydrological cycle are due to the intense deforestation that occurred in the region. Accordingly, there is a local custom where women pray to San Isidro, the patron saint of agriculture and weather when precipitation is too heavy or not heavy enough. This element of women's worldview is an important component of local knowledge, and is the defining factor of local knowledge linked to social networks for adapting water management to abrupt changes in the landscape.

\section{Social networks}

In addition to the women's local knowledge of landscape and climate, their role in social networks was also related to water management. A couple of families had private springs, which made these families independent from the central water supply system (Fig. 3). Other women had access to these private springs and the water from them because of their family ties or relationships based on baptism. This showed strong family networks and positive relationships that were important for sustaining increased water access to more women in the community.

\section{DISCUSSION}

This study was conducted in 2007. Its context is still relevant a decade later, given the role of local knowledge in adaptive resource management in changing rural landscapes (Chaffin and Gunderson 2016) and the "think global, act local"-infused political processes that shape landscape change (Orach and Schlüter 2016). Our results demonstrate how interlinked local 
knowledge of climate, landscape, and social structure were in providing women access to water resources, and enhancing their adaptive capacity during change in Coatitilán. Also, our findings underlined the potential value of using women's local knowledge for local planning processes to better steer development measures toward supporting resilient social-ecological systems.

\section{Key factors related to local knowledge and social networks}

The changes to the women's local environment in and around Coatitilán due to the recent road construction and creation of the trout farm led women to revisit springs that may have been previously known or were easily identified due to the women's deep local knowledge of vegetation and water resources. The women's landscape knowledge suggests the importance of managing and perhaps protecting vegetation for ensuring mountain slope stability, which can both support agricultural production (e.g., less erosion or fewer mudslides protect harvests) and freshwater resources (e.g., springs and streams are not clogged with eroded sediment). Landscape knowledge also facilitated a choice of springs and water resources if some were being used or became unusable through contamination or dry conditions. Women's knowledge of the interrelationship between landscape and climate was tied to their agricultural tasks over the course of a year (Table 2). This means that on a daily basis, throughout each season, rural women's activities allow them to assess the ecological conditions of their environment (Ruiz-Mallén and Corbera 2013, Ruiz-Mallén et al. 2015b, 2015c). Furthermore, climate knowledge was described using local language, which demonstrates a local eco-linguistic body of knowledge, which has been described as an indicator of well-developed ecological knowledge (Maffi 2005). Women's knowledge of the biophysical landscape and climate was holistic, and allowed them to identify cause-and-effect relationships between ecosystem components within their immediate landscape. This knowledge reflects an understanding of ecosystem processes that are cyclical in nature and self-regulate. These key factors related to women's landscape and climate knowledge could be central to sustainable adaptation to slow changes, and underlines the cause for promoting polycentric governance (Biggs et al. 2015) for directing change in rural communities.

Spirituality and worldview are important components of local knowledge; it reinforces the relationship people have with their landscape and its ecosystems, and serves to connect the components of the landscape and climate with community dynamics. This is apparent in the yearly agricultural cycle (Table 2 ), which relies on rituals to help people remember the key customs associated with agriculture and interpret climate and landscape signals accordingly. Like in Coatitilán, landscape change in the Doñana reserve in southern Spain was instigated by the production of new crops for export, which required new management methods. In both cases, people used spiritual rituals (e.g., prayer) to cope with environmental variability (GómezBaggethun et al. 2013a). While the prayer rituals may be ineffective for controlling weather patterns, it has been found that such ceremonies can play an important role in strengthening a community in the face of risks (Berkes et al. 2000). This is likely due to the way in which ceremonies promote community cohesion, reduce likelihood of social disruption, and help communities cope with crises (Gómez-Baggethun et al. 2013b) or abrupt changes. Furthermore, in Coatitilán, kinship through baptism provided certain women with easier access to otherwise private water springs. Therefore, worldview and spirituality are important components of local knowledge that underlie social networks, and help people deal with environmental shocks.

\section{Implications of local knowledge for landscape governance}

Local knowledge may act as a filter of how the environment is perceived, and is significant in determining how people adapt to resource scarcity (Olsson and Folke 2001, Meinzen-Dick et al. 2002, Berkes and Davidson-Hunt 2006). If an environmental problem is perceived as too severe, people may reduce their efforts to take action. Or, if they feel they are already doing enough, they may take no further action (Marshall and Marshall 2007). Since perception is critical in determining whether or not individuals use management strategies to adapt to change (Adger and Winkels 2007), it is important to consider the subjective nature of local knowledge. Individuals may have different points of reference, so they may perceive the same event and condition differently. The way people perceive water availability and scarcity differs between user groups (e.g., women and men), as well as between community members and decision-makers (Larson et al. 2009). These discrepancies may be at the root of problems caused by development in Coatitilán. While development decisions were based on economic development goals, they neglected the degree to which women in their everyday life were affected by the projects. Therefore, understanding how resource change is perceived can be important for water management, since rural communities should have the power to control the future of their landscape and the natural resources contained therein (Murtinho et al. 2013). Had the ejido, municipal government, or project engineers consulted with the women in Coatitilán, they may have learned that the rainy season was the wrong time to conduct road construction and that the construction was problematic for the families' water resources. Without effective governance institutions at the appropriate scale, social-ecological systems continue to be at risk. The case of Coatitilán is an example of how top-down policies and disconnected decision-making regarding rural development may limit access to communal resources, at least for key moments (Berkes et al. 1998a).

While the state and municipal government instigated landscape change in Coatitilán, the feedbacks affected the women living there. As such, there was a disconnect between local knowledge and institutional decision-making, which led to abrupt changes in the community and its surrounding landscape, and intensified the challenges that the community was exposed to (Ruiz-Mallén et al. 2015a). A frequently reported solution in this sense would be decision-making at the community-based level (Peet and Watts 1996). For example, collaboration between local governments and local communities could promote participatory planning processes, which have largely been found to be a successful common resource management tool (Malinga et al. 2013) and potentially inclusive of local knowledge. Consequently, we propose that women's local knowledge as studied here, has a dual potential: on one hand, it can be used for more effective community and natural resource governance, and on the other hand, it helps women adapt to abrupt shocks to the socialecological system, which is exemplified here with the case of freshwater resources. While this study focused on an abrupt change, further research in the area could explore the relationship between local environmental knowledge and slower landscape 
changes. For example, how the completed road has changed local knowledge of the landscape, if freshwater provisioning has proven resilient to other changes, and if there are differences in the nexus of knowledge and management between women living upstream and downstream of the trout farm could all expand our findings. Such future research could contribute to a more complete temporal understanding of social-ecological resilience by comparing faster and slower landscape changes, and the contribution of local knowledge to adaptation and governance in each case.

\section{CONCLUSION}

This study focused on women's local knowledge about their immediate landscape, climate, and role in social networks, and how this knowledge allowed them to deal with abrupt environmental damage due to landscape change. We aimed to answer and discuss the key factors related to the women's knowledge and its implications for social-ecological system governance. Using interviews, participatory methods (i.e., mapping and transect walks), and Berkes' (1999) levels of analysis allowed us to gain a holistic idea of women's local knowledge. It became clear that the daily and seasonal activities in the household and for food production allowed women to monitor their environment, and fed into their knowledge. Vegetation was a key component for regulating water resources and maintaining the landscape topography. Knowledge of climate was linked to women's spirituality and worldview, which seemed to provide a coping mechanism and community cohesion, specifically regarding relationships through baptism. Such kinship was key for some women to gain access to otherwise privately owned springs. Our findings suggest a dualistic purpose of local knowledge. On one hand, it provided a framework for women to adapt to abrupt change, and on the other hand, it could be used to inform future decision-making to make the community, the surrounding landscape, and the natural resources contained therein resilient to both slow and abrupt changes.

Responses to this article can be read online at: http://www.ecologyandsociety.org/issues/responses. php/9787

\section{Acknowledgments: \\ We would like to thank the University of Natural Resources and Life Sciences, Vienna, for funding, Luis Chacon of the Universidad Veracruzana for his support in the field, as well as the women of Coatitilán for their participation in this study.}

\section{LITERATURE CITED}

Adger, W. N., and A. Winkels. 2007. Vulnerability, poverty and sustaining well-being. Pages 206-216 in G. Atkinson, S. Dietz, E. Neumayer, and M. Agarwala, editors. Handbook of sustainable development. Edward Elgar, Cheltenham, UK. http://dx.doi. org/10.4337/9781782544708.00023

Antrop, M. 2005. Why landscapes of the past are important for the future. Landscape and Urban Planning 70:21-34. http://dx.doi. org/10.1016/j.landurbplan.2003.10.002
Arnberger, A., and R. Eder. 2011. Exploring the heterogeneity of rural landscape preferences: an image-based latent class approach. Landscape Research 36:19-40. http://dx.doi. org/10.1080/01426397.2010.536204

Barrera-Brassols, N., and J. A. Zinck. 2002. Ethnopedology: a worldwide view on the soil knowledge of local people. Geoderma 111:171-195. http://dx.doi.org/10.1016/S0016-7061(02)00263-X

Bell, M. M., S. E. Lloyd, and C. Vatovec. 2010. Activating the countryside: rural power, the power of the rural and the making of rural politics. Sociologia Ruralis 50:205-224. http://dx.doi. org/10.1111/j.1467-9523.2010.00512.x

Berkes, F. 1999. Sacred ecology: traditional ecological knowledge and resource management. Taylor \& Francis, Philadelphia, USA.

Berkes, F., J. Colding, and C. Folke. 2000. Rediscovery of traditional ecological knowledge as adaptive management. Ecological Applications 10(5):1251-1262. http://dx.doi. org/10.1890/1051-0761(2000)010[1251:ROTEKA]2.0.CO;2

Berkes, F., and I. J. Davidson-Hunt. 2006. Biodiversity, traditional management systems, and cultural landscapes: examples from the boreal forest of Canada. International Social Science Journal 58:35-47. http://dx.doi.org/10.1111/j.1468-2451.2006.00605.x

Berkes, F., I. Davidson-Hunt, and K. Davidson-Hunt. 1998a. Diversity of common property resource use and diversity of social interests in the western Indian Himalaya. Mountain Research and Development 18(19:19-33).

Berkes, F., and C. Folke. 2002. Panarchy: understanding transformations in human and natural systems. Island Press, Washington, D.C., USA.

Berkes, F., M. Kislalioglu, C. Folke, and M. Gadgil. 1998 b. Minireviews: exploring the basic ecological unit: ecosystem-like concepts in traditional societies. Ecosystems 1:409-415. http://dx. doi.org/10.1007/s100219900034

Bernard, H. R. 2002. Research methods in anthropology: qualitative and quantitative approaches. Third edition. AltaMira Press, Walnut Creek, California, USA.

Biggs, R., M. Schlüter, and M. L. Schoon. 2015. Principles for building resilience: sustaining ecosystem services in socialecological systems. Cambridge University Press, Cambridge, UK. http://dx.doi.org/10.1017/CBO9781316014240

Blaikie, P. 1985. The political economy of soil erosion in developing countries. Longman Scientific and Technical Publishing, New York, New York, USA.

Carney, J. 1996. Converting the wetlands, engendering the environment. Pages 165-186 in R. Peet and M. Watts, editors. Liberation ecologies: environment, development, socialmovements. Routledge, New York, USA.

Chaffin, B. C., and L. H. Gunderson. 2016. Emergence, institutionalization and renewal: rhythms of adaptive governance in complex social-ecological systems. Journal of Environmental Management 165:81-87. http://dx.doi.org/10.1016/j.jenvman.2015.09.003

Coomes, O. T., and G. J. Burt. 1997. Indigenous market-oriented agroforestry: dissecting local diversity in western Amazonia. Agroforestry Systems 37:27-44. http://dx.doi.org/10.1023/ A:1005834816188 
Eakin, H., H. Perales, K. Appendini, and S. Sweeney. 2014. Selling maize in Mexico: the persistence of peasant farming in an era of global markets. Development and Change 45:133-155. http://dx. doi.org/10.1111/dech.12074

Ellis, F. 2000. The determinants of rural livelihood diversification in developing countries. Journal of Agricultural Economics 51:289-302. http://dx.doi.org/10.1111/j.1477-9552.2000.tb01229. $\underline{\mathrm{x}}$

Erb, K. H., F. Krausmann, V. Gaube, S. Gingrich, A. Bondeau, M. Fischer-Kowalski, and H. Haberl. 2009. Analyzing the global human appropriation of net primary production - processes, trajectories, implications. An introduction. Ecological Economics 69:250-259. http://dx.doi.org/10.1016/j.ecolecon.2009.07.001

Fernandez-Gimenez, M. E., and F. F. Estaque. 2012. Pyrenean pastoralists' ecological knowledge: documentation and application to natural resource management and adaptation. Human Ecology 40:287-300. http://dx.doi.org/10.1007/s10745-012-9463$\underline{\mathrm{X}}$

Fischer, J., T. A. Gardner, E. M. Bennett, P. Balvanera, R. Biggs, S. Carpenter, T. Daw, C. Folke, R. Hill, T. P. Hughes, T. Luthe, M. Maass, M. Meacham, A. V. Norstrom, G. Peterson, C. Queiroz, R. Seppelt, M. Spierenburg, and J. Tenhunen. 2015. Advancing sustainability through mainstreaming a socialecological systems perspective. Current Opinion in Environmental Sustainability 14:144-149. http://dx.doi.org/10.1016/j.cosust.2015.06.002

Food and Agriculture Organization of the United Nations (FAO). 2015. Why gender: key facts. Rome, Italy. http:// www.fao.org/ gender/gender-home/gender-why/key-facts/en/

Garcia-Barrios, L., Y. M. Galvan-Miyoshi, I. A. Valdivieso-Perez, O. R. Masera, G. Bocco, and J. Vandermeer. 2009. Neotropical forest conservation, agricultural intensification, and rural outmigration: the Mexican experience. Bioscience 59:863-873. http:// dx.doi.org/10.1525/bio.2009.59.10.8

Gibbs, G. R. 2007. Analyzing qualitative data. Sage, Thousand Oaks, California, USA. http://dx.doi.org/10.4135/9781849208574

Glaser, B. G., and A. L. Strauss. 1967. The discovery of grounded theory: strategies for qualitative research. Aldine Publishing Company, Chicago, Illinois, USA.

Gómez-Baggethun, E., E. Corbera, and V. Reyes-Garcia. $2013 a$. Traditional ecological knowledge and global environmental change: research findings and policy implications. Ecology and Society 18(4):72. http://dx.doi.org/10.5751/ES-06288-180472

Gómez-Baggethun, E., E. Kelemen, B. Martin-Lopez, I. Palomo, and C. Montes. 2013b. Scale misfit in ecosystem service governance as a source of environmental conflict. Society \& Natural Resources 26:1202-1216. http://dx.doi.org/10.1080/08941920.2013.820817

Hoffmann, O. 1993. Rumbos y paisajes de Xico. Geografía de un municipio de la sierra Veracruzana. ORSTROM: L'Institut Français de Recherche Scientific pour le Développment en Coopération. Instituto de Ecología, A.C. Xalapa, Veracruz, Mexico.

Lambin, E. F., H. K. Gibbs, L. Ferreira, R. Grau, P. Mayaux, P. Meyfroidt, D. C. Morton, T. K. Rudel, I. Gasparri, and J. Munger.
2013. Estimating the world's potentially available cropland using a bottom-up approach. Global Environmental Change 23:892901. http://dx.doi.org/10.1016/j.gloenvcha.2013.05.005

Lambin, E. F., and P. Meyfroidt. 2010. Land use transitions: socio-ecological feedback versus socio-economic change. Land Use Policy 27:108-118. http://dx.doi.org/10.1016/j.landusepol.2009.09.003

Lambin, E. F., B. L. Turner, H. J. Geist, S. B. Agbola, A. Angelsen, J. W. Bruce, O. T. Coomes, R. Dirzo, G. Fischer, C. Folke, P. S. George, K. Homewood, J. Imbernon, R. Leemans, X. B. Li, E. F. Moran, M. Mortimore, P. S. Ramakrishnan, J. F. Richards, H. Skanes, W. Steffen, G. D. Stone, U. Svedin, T. A. Veldkamp, C. Vogel, and J. C. Xu. 2001. The causes of land-use and land-cover change: moving beyond the myths. Global Environmental Change 11:261-269. http://dx.doi.org/10.1016/S0959-3780(01)00007-3

Larson, K. L., D. D. White, P. Gober, S. Harlan, and A. Wutich. 2009. Divergent perspectives on water resource sustainability in a public-policy-science context. Environmental Science \& Policy 12:1012-1023. http://dx.doi.org/10.1016/j.envsci.2009.07.012

Maffi, L. 2005. Linguistic, cultural, and biological diversity. Annual Review of Anthropology 34:599-617. http://dx.doi. org/10.1146/annurev.anthro.34.081804.120437

Malinga, R., L. J. Gordon, R. Lindborg, and G. Jewitt. 2013. Using participatory scenario planning to identify ecosystem services in changing landscapes. Ecology and Society 18(4):10. http://dx.doi.org/10.5751/ES-05494-180410

Margana Cruz, G. 2006. Estudio de Impacto Ambiental de la granja acuícola comunitaria. Tesis, Universidad Veracruzana, Xalapa, Mexico.

Marshall, N. A., and P. A. Marshall. 2007. Conceptualizing and operationalizing social resilience within commercial fisheries in northern Australia. Ecology and Society 12(1):1. http://dx.doi. org/10.5751/ES-01940-120101

Meinzen-Dick, R., K. V. Raju, and A. Gulati. 2002. What affects organization and collective action for managing resources? Evidence from canal irrigation systems in India. World Development 30:649-666. http://dx.doi.org/10.1016/S0305-750X (01)00130-9

Murtinho, F., C. Tague, B. de Bievre, H. Eakin, and D. LopezCarr. 2013. Water scarcity in the Andes: a comparison of local perceptions and observed climate, land use and socioeconomic changes. Human Ecology 41: 667-681. http://dx.doi.org/10.1007/ s10745-013-9590-Z

National Institute of Statistics and Geography (INEGI). 2005. Conteo de Población y Vivienda. http://www.inegi.org.mx

Newing, H. 2011. Conducting research in conservation: social science methods and practice. Routledge, New York, New York, USA.

Olsson, P., and C. Folke. 2001. Local ecological knowledge and institutional dynamics for ecosystem management: a study of Lake Racken Watershed, Sweden. Ecosystems 4:85-104. http:// dx.doi.org/10.1007/s100210000061

Orach, K., and M. Schlüter. 2016. Uncovering the political dimension of social-ecological systems: contributions from policy 
process frameworks. Global Environmental Change 40:13-25. http://dx.doi.org/10.1016/j.gloenvcha.2016.06.002

Peet, R., and M. Watts. 1996. Liberation ecology: development, sustainability and environment in the age of market triumphalism. Pages 1-45 in Liberation ecologies: environment, development, socialmovements. Routledge, New York, New York, USA.

Plieninger, T., and C. Bieling, editors. 2012. Resilience and the cultural landscape - understanding and managing change in humanshaped environments. Cambridge University Press,,Cambridge, UK. http://dx.doi.org/10.1017/CBO9781139107778

Ray, I. 2007. Women, water, and development. Annual Review of Environment and Resources 32:421-449. http://dx.doi.org/10.1146/ annurev.energy.32.041806.143704

Ruiz-Mallén, I., and E. Corbera. 2013. Community-based conservation and traditional ecological knowledge: implications for social-ecological resilience. Ecology and Society 18(4):12. http://dx.doi.org/10.5751/ES-05867-180412

Ruiz-Mallén, I., E. Corbera, D. Calvo-Boyero, and V. ReyesGarcia.2015a. Participatory scenarios to explore local adaptation to global change in biosphere reserves: experiences from Bolivia and Mexico. Environmental Science \& Policy 54:398-408. http:// dx.doi.org/10.1016/j.envsci.2015.07.027

Ruiz-Mallén, I., E. Corbera, D. Calvo-Boyero, V. Reyes-Garcia, and K. Brown. 2015b. How do biosphere reserves influence local vulnerability and adaptation? Evidence from Latin America. Global Environmental Change 33:97-108. http://dx.doi. org/10.1016/j.gloenvcha.2015.05.002

Ruiz-Mallen, I., C. Schunko, E. Corbera, M. Rös, and V. ReyesGarcia. 2015c. Meanings, drivers, and motivations for community-based conservation in Latin America. Ecology and Society 20(3):33. http://dx.doi.org/10.5751/ES-07733-200333

Servicio Meteorologico Nacional Database. 2007. http://smn.cna. gob.mx

United Nations Educational, Scientific and Cultural Organization (UNESCO). 2015. The United Nations world water development report 2015: water for a sustainable world. United Nations World Water Assessment Programme, Paris, France.

Urquijo, P. S., and G. J. F. Bocco. 2011. Los estudios de paisaje y su importancia en México, 1970-2010. Journal of Latin American Geography 10(2):37-63. http://dx.doi.org/10.1353/lag.2011.0025

Urquijo Torres, P. S., and N. Barrera Bassols. 2009. Historia y paisaje: Explorando un concepto geográfico monista Andamios. Revista de Investigación Social 5(10):227-252.

Vogl, C. R., B. Vogl-Lukasser, and R. K. Puri. 2004. Tools and methods for data collection in ethnobotanical studies of homegardens. Field Methods 16:285-306. http://dx.doi. org/10.1177/1525822X04266844

Williams-Linera, G. 2007. El bosque de niebla del centro de Veracruz: ecología, history y destino en tiempos de fragmentactión y cambio climático. Instituto de Ecologia: Comisión Nacional para el Conocimiento y Uso de la Biodiversidad Xalapa, Veracruz, México.
Wu, J. 2013. Landscape sustainability science: ecosystem services and human well-being in changing landscapes. Landscape Ecology 28:999-1023. http://dx.doi.org/10.1007/s10980-013-9894-9

Zwarteveen, M. Z. 1997. Water: from basic need to commodity: a discussion on gender and water rights in the context of irrigation. World Development 25:1335-1349. http://dx.doi. org/10.1016/S0305-750X(97)00032-6 